\title{
Van zorginstellingen, zorgverzekeraars en patiëntenverenigingen en het wetsvoorstel Wet bestuur en toezicht rechtspersonen
}

\author{
A.G.H. Klaassen
}

\section{Inleiding}

In juni 2016 is het wetsvoorstel Wet bestuur en toezicht rechtspersonen (WBTR) ${ }^{1}$ door de minister van Veiligheid en Justitie aangeboden aan de Tweede Kamer. Met deze wet wordt een aantal regels die al gelden voor de nv en de bv verplaatst naar de algemene titel van Boek 2 van het Burgerlijk Wetboek (BW). Door de bedoelde regels op te nemen in het algemene gedeelte gelden zij ook voor de vereniging, de coöperatie, de onderlinge waarborgmaatschappij (OWM) en de stichting.

Voor de gezondheidszorg kan deze wet belangrijke gevolgen hebben omdat organisaties in deze sector juist van deze rechtsvormen gebruik maken. De stichting is nog steeds de meest voorkomende rechtsvorm voor zorginstellingen. ${ }^{2}$ (Patiënten)verenigingen behartigen de belangen van hun leden. Zorgverzekeraars kunnen, naast de nv, de rechtsvorm van een $\mathrm{OWM}^{3}$ hebben. ${ }^{4}$

De centrale vragen zijn:

1 Wat betekent de WBTR voor zorginstellingen, patiëntenverenigingen en zorgverzekeraars?

2 Zijn deze gevolgen wenselijk?

3 Is aanpassing van sectorale regelgeving nodig of gewenst?

De opzet van deze bijdrage is als volgt. In paragraaf 2 ga ik eerst kort in op de WBTR. Daarna behandel ik in paragraaf 3 de WBTR in verhouding met sectorale regelgeving. In paragraaf 4 komt het instellen van een raad van commissarissen aan de orde. Paragraaf 5 gaat over het monistisch bestuursmodel. De norm die bestuurders en commissarissen in acht dienen te nemen bij de vervulling van hun taak is het onderwerp van paragraaf 6 . Paragraaf 7 gaat over de tegenstrijdigbelangregeling. Paragraaf 8 stelt de aansprakelijkheid van bestuurders en com-

1 Kamerstukken II 2015/16, 34491, 2.

2 Zie www.jaarverslagenzorg.nl. Wanneer over zorginstellingen wordt gesproken, wordt uitgegaan van de rechtsvorm stichting, tenzij anders vermeld.

3 Op grond van art. 3:20 Wft is een Europese vennootschap ook mogelijk. In de praktijk zien we dat de 'moeder' van een (zorg)verzekeringsconcern een coöperatie is, zoals VGZ en Menzis.

4 Wanneer over zorgverzekeraars wordt gesproken, wordt uitgegaan van de rechtsvorm OWM, tenzij anders vermeld. 
Van zorginstellingen, zorgverzekeraars en patiëntenverenigingen en het wetsvoorstel Wet bestuur en toezicht rechtspersonen

missarissen aan de orde. In paragraaf 9 komt het ontslag van bestuurders en commissarissen aan bod. In paragraaf 10 volgt de conclusie.

\section{Wet bestuur en toezicht rechtspersonen}

Belangrijkste doel van de WBTR is de regels op een aantal onderwerpen voor alle rechtspersonen te uniformeren. Daarbij is de WBTR met name gericht op verbetering van het wettelijke kader voor de vereniging, de coöperatie, de OWM en de stichting. De WBTR beoogt de regeling voor bestuur en toezicht bij de verschillende soorten rechtspersonen aan te vullen en te verduidelijken. Hiermee wordt volgens de memorie van toelichting voorzien in een behoefte van de praktijk. ${ }^{5}$

De WBTR vormt verder de hoeksteen van de maatregelen ter verbetering van de kwaliteit van bestuur en toezicht bij verenigingen en stichtingen in de semipublieke sector, ${ }^{6}$ zoals deze zijn aangekondigd in een brief aan de Tweede Kamer in 2013. ${ }^{7}$ Door de algemene titel van Boek 2 BW uit te breiden ${ }^{8}$ betekent dit wel dat de regels gaan gelden voor alle rechtspersonen, ook voor rechtspersonen buiten de semipublieke sector. ${ }^{9}$ Niet alleen de beoogde onderwijsinstellingen, woningcorporaties en zorginstellingen worden geraakt door deze wet, maar - indien we het hebben over de gezondheidszorg - ook patiëntenverenigingen en zorgverzekeraars kunnen gevolgen ondervinden van deze wet.

Belangrijke elementen van dit wetsvoorstel zijn dat er voor alle rechtspersonen een wettelijke grondslag komt voor de mogelijkheid tot instelling van een raad van commissarissen (art. 2:11 BW (nieuw)). Ook wordt het voor alle rechtspersonen mogelijk te kiezen voor een monistisch bestuurssysteem (art. 2:9a BW (nieuw)). Verder krijgen de vereniging, de coöperatie, de OWM en de stichting regels over (1) de norm die bestuurders en commissarissen bij de vervulling van hun taak in acht moeten nemen (art. 2:9 lid 3 en 2:11 lid 4 BW (nieuw)), (2) de positie van bestuurders en commissarissen met een tegenstrijdig belang (art. 2:9 lid 5 en 2:11 lid 6 BW (nieuw)) en (3) de aansprakelijkheid van bestuurders en commissarissen (art. 2:9b, 2:9c, 2:11b en 2:11c BW (nieuw)). Tot slot wordt de regeling voor ontslag van een stichtingsbestuurder door de rechter aangepast. De

$5 \quad$ Kamerstukken II 2015/16, 34491, 3, p. 1.

6 Kamerstukken II 2015/16, 34491, 3, p. 3.

7 Kamerstukken II 2013/14, 33750 VI, 31.

8 Vraag is of het wetstechnisch wenselijk is deze regels in de algemene titel te plaatsen of deze 'te herhalen' in de titel per rechtspersoon. Mijn voorkeur gaat uit naar het laatste, vanwege de leesbaarheid, de overzichtelijkheid en omdat per rechtsvorm kan worden ingespeeld op de 'echte' behoeftes uit de praktijk. Door plaatsing van bepaalde regels in de algemene titel worden de rechtspersonen (te veel) over één kam geschoren. De rechtsvormen stichting en vereniging kennen zeer verschillende verschijningsvormen. Zie ook J.B. Huizink, De voorgestelde wijzigingen van titel 1 Boek 2 BW, in: J.M. Blanco Fernández e.a., Bestuur en toezicht bij rechtspersonen, mede in de semipublieke en non-profitsector, Zutphen: Uitgeverij Paris 2016, p. 22, 23, 27 en 29.

9 Zie hierover S.M. Bartman, C. de Groot, J. Nijland \& I.S. Wuisman, Enkele kanttekeningen bij het wetsvoorstel bestuur en toezicht rechtspersonen, MvO 2016, p. 227-233. 
ontslagregeling komt daarbij ook te gelden voor commissarissen van een stichting (art. 2:298 BW (nieuw)). ${ }^{10}$

\section{Verhouding tot sectorale regelgeving}

Het is de bedoeling dat door de aanvulling en verduidelijking van de regels van rechtspersonen in Boek 2 BW deze regels beter bruikbaar worden als basisregeling. ${ }^{11}$ In sectorspecifieke regelgeving kunnen eventueel aanvullende regels worden gesteld. Daarbij kan zo nodig ook van de algemene basisregeling in Boek 2 BW worden afgeweken, mits het geen dwingend recht betreft. ${ }^{12}$

Gezien de verschillende initiatieven die de ministers van Onderwijs, Cultuur en Wetenschap en Binnenlandse Zaken en Koninkrijksrelaties hebben genomen ${ }^{13}$ en de (oorspronkelijke) plannen van de minister van Volksgezondheid, Welzijn en Sport (VWS), ${ }^{14}$ komt de WBTR niet te vroeg. Zoals de minister van VWS terecht opmerkt, moeten onderwerpen die sectoroverstijgend zijn, zoals de taak en de aansprakelijkheid van (interne) toezichthouders en de norm van taakvervulling, worden opgenomen in algemene wetgeving. ${ }^{15}$

Voor zorginstellingen stellen de Wet toelating zorginstellingen (WTZi) en het Uitvoeringsbesluit WTZi extra eisen aan de bestuursstructuur van zorginstellingen in aanvulling op de regels van Boek 2 BW. ${ }^{16}$ Daarnaast geldt voor zorginstellingen de Governancecode Zorg. Deze code geldt per 1 januari 2017.17

Voor zorgverzekeraars geldt naast Boek 2 BW de Wet op het financieel toezicht $(\mathrm{Wft})^{18}$ en de Zorgverzekeringswet (Zvw). ${ }^{19}$ Bovendien is de Gedragscode Goed Zorgverzekeraarschap van toepassing. ${ }^{20}$ Voor patiëntenverenigingen geldt geen

10 Kamerstukken II 2015/16, 34491, 3, p. 1.

11 Kamerstukken II 2015/16, 34491, 3, p. 8.

12 Kamerstukken II 2015/16, 34491, 3, p. 3.

13 Zie bijv. de Wet versterking kwaliteitswaarborgen hoger onderwijs, Stb. 2013, 558 en de Herzieningswet toegelaten instellingen volkshuisvesting, Stb. 2015, 145-146.

14 Er is voorlopig geen separaat wetsvoorstel Goed bestuur en medezeggenschap te verwachten. Zie Kamerstukken II 2014/15, 32012, 23. Bovendien lijkt VWS bijna geheel in te zetten op aanpassing van de toen geldende Zorgbrede Governancecode. Zie hierover A.G.H. Klaassen, Geen wetsvoorstel Goed bestuur in de zorg: terecht of niet?, TvGR 2016, p. 128 e.v.

15 Kamerstukken II 2014/15, 32012, 24, p. 23.

16 Art. 7 lid 3 sub c jo. art. 9 lid 1 sub b WTZi en art. 6.1 t/m 6.5 Uitvoeringsbesluit WTZi. Zie art. 3 van het ambtelijk voorontwerp Wet toetreding zorgaanbieders, www.internetconsultatie.nl/wet_ toetreding_zorgaanbieders.

17 Zie www.governancecodezorg.nl.

18 Zie met name afdeling 3.3.2.

19 Zie art. 28 Zvw.

20 De Governance Principes Verzekeraars zijn per 1 januari 2016 vervallen. Zie www.verzekeraars. $\mathrm{nl} /$ actueel/nieuwsberichten/Paginas/Verzekeraars-leven-zelfregulering-goed-na.aspx. Reden is dat vrijwel alle Governance Principes, die dateren uit 2011, inmiddels zijn verankerd in wetgeving. Elementen die niet zijn verankerd, hebben een plaats gekregen in de Gedragscode Verzekeraars 2015. Deze laatste code is van toepassing indien een zorgverzekeraar lid is van het Verbond van Verzekeraars. 
vergelijkbare regelgeving. ${ }^{21} \mathrm{Zij}$ kunnen gebruik maken van de Toolkit Goed Bestuur. ${ }^{22}$ Deze sectorale regelgeving blijft ook na inwerkingtreding van de WBTR van kracht.

\section{Wettelijke grondslag voor raad van commissarissen}

Art. 2:11 BW (nieuw) biedt een uitdrukkelijke grondslag voor het instellen van een raad van commissarissen. Hiermee wordt voorzien in een belangrijke behoefte van de praktijk, aldus de memorie van toelichting. Het instellen van een raad van commissarissen zelf blijft facultatief. ${ }^{23}$ Bij statuten moet worden bepaald dat er een raad van commissarissen is. Met een raad van commissarissen kiest de rechtspersoon dan voor een dualistisch bestuursmodel.

Boek 2 BW kiest voor de term 'raad van commissarissen' en niet voor 'raad van toezicht'. In de sectorale wetten ${ }^{24}$ en de praktijk - vooral bij stichtingen - wordt de laatste benaming veelal gehanteerd. Wetssystematisch ligt het ook niet voor de hand om binnen Boek 2 BW verschillende benamingen te hanteren voor organen die in feite dezelfde functie vervullen, zo staat in de memorie van toelichting. ${ }^{25}$

Wanneer in de statuten een orgaan van de rechtspersoon wordt ingesteld, is dat orgaan alleen een raad van commissarissen in de zin van Boek 2 BW indien aan dat orgaan de taak wordt toegekend om toezicht te houden op het beleid van het bestuur en op de algemene gang van zaken in de rechtspersoon en de daaraan verbonden onderneming of organisatie. In dat geval heeft het orgaan ook de (andere) taken en bevoegdheden die door Boek 2 BW aan een raad van commissarissen worden toebedeeld. ${ }^{26}$

De WBTR beoogt niet om wijziging te brengen in bestaande bestuurs- en toezichtsstructuren bij de verschillende soorten rechtspersonen. De WBTR bevat volgens de memorie van toelichting vooral een verduidelijking van het reeds geldende juridische kader. ${ }^{27}$

\subsection{Zorginstellingen}

Aangezien Boek 2 BW na invoering van de WBTR alleen de grondslag voor het instellen van een raad van commissarissen bevat, is nog steeds sectorale regelgeving nodig voor het verplicht instellen van een raad van commissarissen. Op grond van art. 6.1 Uitvoeringsbesluit WTZi is een zorginstelling verplicht een

21 Het Besluit vaststelling beleidskader inzake subsidiëring van patiënten- en gehandicaptenorganisaties, Stcrt. 2016, 37565 stelt als eis dat de vereniging volledig rechtsbevoegd is volgens Boek 2 BW om bepaalde subsidies te kunnen verkrijgen. Indien het gaat om een stichting, dan dient zij, naast een bestuur, te beschikken over een toezichthoudend orgaan.

22 Zie www.pgosupport.nl/page/Toolkits? $\bmod [1508][\mathrm{f}]=19 \& \bmod [1508][i]=107$. PGOsupport is een onafhankelijke netwerkorganisatie voor patiënten- en gehandicaptenorganisaties. PGOsupport adviseert deze organisaties en ondersteunt initiatieven die hun positie versterken.

23 Kamerstukken II 2015/16, 34491, 3, p. 4.

24 Zie bijv. art. 30 Woningwet en art. 9.7 WHW.

25 Kamerstukken II 2015/16, 34491, 3, p. 20.

26 Kamerstukken II 2015/16, 34491, 3, p. 20.

27 Kamerstukken II 2015/16, 34491, 3, p. 1. 
toezichthoudend orgaan in te stellen. In dit lid staat: '[E]r is een orgaan dat toezicht houdt op het beleid van de dagelijkse of algemene leiding van de instelling en deze met raad ter zijde staat.' Het toezichthoudend orgaan waarop het Uitvoeringsbesluit WTZi doelt, kan een raad van commissarissen zijn in de zin van Boek 2 BW. ${ }^{28}$ Dat zal het geval zijn bij het gebruikelijke raad-van-toezichtmodel. ${ }^{29}$

Voor de verplichting tot het instellen van een toezichthoudend orgaan leent zich sectorspecifieke regelgeving. Een dergelijke verplichting past niet in Boek 2 BW. Bij zorgstichtingen wordt de term 'raad van toezicht' gebruikt. Dit is ook de term in de Governancecode Zorg. De benaming van het toezichthoudend orgaan is, zoals gezegd, niet bepalend voor de juridische kwalificatie van dat orgaan. Ook een toezichthoudend orgaan dat wordt aangeduid als 'raad van toezicht' kan een raad van commissarissen zijn in de zin van Boek 2 BW. ${ }^{30}$ Ik raad aan de term raad van commissarissen te gaan gebruiken. ${ }^{31}$ Dit kan bij een toekomstige statutenwijziging. Indien VWS van mening blijft dat voor zorginstellingen het dualistisch model het enige toegestane model is, kan de tekst van het Uitvoeringsbesluit WTZi worden aangepast, bijvoorbeeld: 'De toegelaten instelling heeft een raad van commissarissen. ${ }^{32}$

\subsection{Patiëntenverenigingen}

Het overgrote deel van de patiëntenverenigingen zal geen raad van commissarissen hebben. Die behoefte zullen deze verenigingen ook niet hebben. Vaker zal gekozen zijn voor een kascommissie. ${ }^{33}$ Een kascommissie die alleen tot taak heeft om toezicht te houden op de financiële gang van zaken binnen de patiëntenvereniging is geen raad van commissarissen in de zin van art. 2:11 BW (nieuw). ${ }^{34}$

Een raad van advies, waarin meestal medisch specialisten zitten op het gebied van (een) specifieke ziekte(n) of aandoening(en), komt ook met enige regelmaat voor bij patiëntenverenigingen. ${ }^{35}$ Deze raden van advies zijn na invoering van het wetsvoorstel nog steeds mogelijk en worden niet beschouwd als raad van commis-

Zie ook B.C.M. Waaijer, Wat betekent het wetsvoorstel voor de statutaire inrichting van vereniging en stichtingen?, in: J.M. Blanco Fernández e.a., Bestuur en toezicht bij rechtspersonen, mede in de semipublieke en non-profitsector, Zutphen: Uitgeverij Paris 2016, p. 62.

29 Art. 6.1 Uitvoeringsbesluit WTZi staat door de formulering ook een Raad van Beheer-model toe. Dit model is nog mogelijk na invoering van de WBTR indien het toezichthoudende orgaan kwalificeert als een bestuur in de zin van Boek 2 BW. Aan de directie zal dan de dagelijkse leiding moeten zijn opgedragen. Er dient een strikte scheiding te bestaan tussen bestuur en directie. Zie de inleiding op de Zorgbrede Governancecode van 2010, p. 10 en www.wtzi.nl/Media/Default/PDF/ Transparantie-eisen.pdf.

30 Kamerstukken II 2015/16, 34491, 3, p. 4.

31 Zie ook Waaijer 2016, p. 62.

32 Zie par. 5.

33 Art. 2:48 lid 2 BW.

34 Dit volgt uit de MvT, Kamerstukken II 2015/16, 34491, 3, p. 20.

35 Zie art. 19 van de statuten van Vereniging voor Mensen met Constitutioneel Eczeem, www.vmce. nl/over-de-vmce/de-vereniging.html. Art. 19 lid 3 luidt: 'Als lid van de adviesraad kunnen door het bestuur personen worden benoemd - al dan niet op voordracht, maar in elk geval in overleg met de reeds zittende leden van deze adviesraad - die vanuit hun vakdiscipline of anderszins de vereniging kunnen adviseren met betrekking tot aspecten ten aanzien van constitutioneel eczeem.' 
sarissen in de zin van Boek 2 BW. Een orgaan dat bijvoorbeeld enkel tot taak heeft om het bestuur te adviseren binnen de rechtspersoon, is derhalve geen raad van commissarissen in de zin van Boek 2 BW, zo volgt uit de memorie van toelichting. ${ }^{36}$

\subsection{Zorgverzekeraars}

Voor zorgverzekeraars met de rechtsvorm OWM bestaat de verplichting voor een toezichthoudend orgaan op grond van art. 28 lid 1 onderdeel a Zvw. ${ }^{37}$ In deze bepaling staat:

'De statuten van een zorgverzekeraar voorzien in toezicht op het beleid van het bestuur en op de algemene gang van zaken in de rechtspersoon en de daarmee verbonden onderneming.'

Uit de memorie van toelichting bij de Zvw blijkt dat het gaat om een raad van commissarissen. Met deze tekst is aangeknoopt bij art. 2:57 en 2:140 BW. ${ }^{38}$ Dit toezichthoudend orgaan, ongeacht de benaming, zal een raad van commissarissen zijn in de zin van Boek 2 BW. In de praktijk wordt al de term 'raad van commissarissen' gebruikt.

\section{Monistisch bestuursmodel}

Boek 2 BW gaat met de WBTR aan alle rechtspersonen de mogelijkheid bieden te kiezen voor een monistisch bestuursmodel. De rechtspersoon kan zelf kiezen welk bestuursmodel, het dualistisch of het monistisch bestuursmodel, het beste bij hem past. Boek 2 BW bevat naar huidig recht alleen voor de nv en bv regels voor het monistisch bestuursmodel. ${ }^{39}$ In het kader van de rechtszekerheid is ervoor gekozen om het monistisch bestuurssysteem ook bij de andere rechtspersonen wettelijk te regelen. ${ }^{40}$

Overigens kan de mogelijkheid om te kiezen voor een monistisch bestuursmodel in sectorspecifieke regelgeving worden uitgesloten, zo staat in de memorie van toelichting. Het voorgestelde art. 2:9a BW (nieuw) sluit niet uit dat in bijzondere wetgeving voor bepaalde instellingen de verplichting wordt opgenomen om een dualistisch bestuursmodel te hanteren. ${ }^{41}$

Kamerstukken II 2015/16, 34491, 3, p. 20-21. De voorgestelde regeling heeft overigens geen gevolgen voor de geldigheid van bestaande organen die in de statuten van een rechtspersoon zijn ingesteld, zie Kamerstukken II 2015/16, 34491, 3, p. 4.

37 Zie art. 3:19 Wft voor de nv.

38 Kamerstukken II 2003/04, 29763, 3, p. 133.

39 Zie de Wet van 6 juni 2011 tot wijziging van Boek 2 van het Burgerlijk Wetboek in verband met de aanpassing van regels over bestuur en toezicht in naamloze en besloten vennootschappen, Stb. 2011, 275.

40 Kamerstukken II 2015/16, 34491, 3, p. 4.

41 Kamerstukken II 2015/16, 34491, 3, p. 4 en 15. 


\subsection{Zorginstellingen}

Zorgstichtingen kunnen geen gebruik maken van art. 2:9a BW (nieuw). In art. 6.1 lid 1 onderdeel a Uitvoeringsbesluit WTZi staat dat bij een zorginstelling 'geen enkel persoon tegelijk deel uit kan maken van het toezichthoudend orgaan en de dagelijkse of algemene leiding'. Een monistisch bestuursmodel is dan niet mogelijk. ${ }^{42}$ Hoewel in de memorie van toelichting bij de WBTR uitdrukkelijk wordt vermeld dat sectorale regelgeving alleen een dualistisch bestuursmodel mag voorschrijven, is in mijn ogen op dit punt aanpassing van het Uitvoeringsbesluit WTZi gewenst. ${ }^{43}$ De voornoemde tekst dient te worden geschrapt. De kwaliteit van het toezicht is niet afhankelijk van de keuze voor een monistische of dualistische bestuursstructuur.

\subsection{Patiëntenverenigingen}

Er zijn patiëntenverenigingen die gebruik maken van een algemeen bestuur en een dagelijks bestuur. De vraag is hoe dit moet worden gekwalificeerd in de context van het wetsvoorstel. Volgens de memorie van toelichting is het 'dagelijks bestuur' alleen te beschouwen als het bestuur in de zin van Boek 2 BW als dit orgaan bevoegd is tot het bepalen van het dagelijkse beleid en de strategie van de rechtspersoon en het zijn taak in beginsel autonoom vervult. Een voorbeeld van een patiëntenvereniging met een bestuur en een dagelijks bestuur is de Hiv Vereniging. Art. 9 lid 2 van de statuten van de Hiv Vereniging luidt:

'Het bestuur is meer in het bijzonder verantwoordelijk voor het nemen van alle strategische en tactische beslissingen met betrekking tot het door de vereniging voorgestane beleid.'

Het dagelijks bestuur, dat volgens art. 8 van de statuten van de Hiv Vereniging bestaat uit de voorzitter, de secretaris en de penningmeester, zal mijns inziens geen bestuur zijn in de zin van Boek 2 BW. ${ }^{44}$

Volgens de memorie van toelichting is het ook mogelijk dat het 'dagelijks bestuur' vooral uitvoerende taken heeft en dat de wettelijke algemene bestuurstaak berust bij het 'algemeen bestuur'. Wanneer de leden van het dagelijks bestuur in dat geval ook lid zijn van het algemeen bestuur, zijn deze leden mogelijk te beschouwen als bestuurders aan wie bij de onderlinge taakverdeling bepaalde uitvoerende

Zie ook L.G.H.J. Houwen, Herzieningswet bestuur en toezicht: effecten voor het semipublieke domein, TvOB 2014, p. 139.

43 A.G.H. Klaassen, Professionalisering van intern toezicht bij zorgaanbieders, TvGR 2013, p. 336. Zie ook Houwen 2014, p. 140; E. Plomp, De Wet bestuur en toezicht rechtspersonen: een aanwinst voor de zorgsector, in: J.M. Blanco Fernández e.a., Bestuur en toezicht bij rechtspersonen, mede in de semipublieke en non-profitsector, Zutphen: Uitgeverij Paris 2016, p. 141.

44 Vgl. art. 7, 8 en 9 van de statuten van de Hiv Vereniging Nederland, www.hivnet.org/. Art. 7 lid 1 luidt: 'Het bestuur bestaat uit ten minste drie meerderjarige personen.' Art. 7 lid 4 luidt: 'De voorzitter wordt in functie benoemd. Het bestuur kiest uit zijn midden een vice-voorzitter, een secretaris en een penningsmeester.' Art. 8 luidt: 'Het dagelijks bestuur bestaat uit de voorzitter, de secretaris en de penningmeester.' 
taken zijn toebedeeld. Dit komt overeen met wat staat in de statuten van de ApneuVereniging. ${ }^{45}$

Hoewel over de genoemde praktijkvoorbeelden de memorie van toelichting helderheid verschaft, is de vraag of een algemeen bestuur of een dagelijks bestuur kwalificeert als het bestuur in de zin van Boek 2 BW niet in algemene zin te beantwoorden, zo staat in dezelfde memorie van toelichting. ${ }^{46}$ Mede vanwege de gevolgen voor de aansprakelijkheid van bestuurders en toezichthouders is duidelijkheid over dit onderwerp gewenst. ${ }^{47}$

\subsection{Zorgverzekeraars}

Met art. 28 lid 1 onderdeel a Zvw is aangeknoopt bij art. 2:57 en 2:140 BW, zo staat in de memorie van toelichting bij de Zvw. ${ }^{48}$ Deze memorie van toelichting stamt uit een periode dat het monistisch bestuursmodel nog niet gangbaar was in Nederland. Het lijkt mij dat de formulering van art. 28 lid 1 onderdeel a Zvw, 'voorzien in toezicht op het beleid van het bestuur en op de algemene gang van zaken in de rechtspersoon en de daarmee verbonden onderneming', ruimte biedt voor het monistisch bestuursmodel bij een zorgverzekeraar met de rechtsvorm OWM. Deze mogelijkheid is er echter niet zolang De Nederlandsche Bank (DNB) vasthoudt aan haar standpunt dat een verzekeraar een intern orgaan heeft dat een met die van een raad van commissarissen vergelijkbare taak heeft. ${ }^{49}$

\section{Norm voor taakvervulling van bestuurders en commissarissen}

De norm waarnaar bestuurders en commissarissen zich bij de vervulling van hun taak moeten richten, wordt met de WBTR geüniformeerd. Bij verenigingen, coöperaties, OWM's en stichtingen ontbreekt een dergelijke normstelling voor

45 Zie art. 8 en 11 van de statuten van de ApneuVereniging, www.apneuvereniging.nl/devereniging/statuten-en-reglementen. Art. 8 lid 1: 'Het bestuur bestaat uit ten minste drie en ten hoogste dertien natuurlijke personen. Het bestuur kiest uit zijn midden een voorzitter, een secretaris en een penningmeester. (...) De voorzitter, de secretaris en de penningmeester vormen het dagelijks bestuur.' Art. 11 lid 1: 'Behoudens de beperkingen volgens de statuten is het bestuur belast met het besturen van de vereniging. Het dagelijks bestuur is belast met de dagelijkse leiding van de vereniging. Het bestuur kan, tot wederopzegging, taken en bevoegdheden delegeren aan het dagelijks bestuur.'

46 Zie hierover Kamerstukken II 2015/16, 34491, 3, p. 21.

47 Waaijer 2016, p. 69.

48 Kamerstukken II 2003/04, 29763, 3, p. 133.

49 Zie www.toezicht.dnb.nl/binaries/50-233287.pdf (via www.toezicht.dnb.nl/3/50-226002.jsp). Wanneer art. 3:19 lid $1 \mathrm{Wft}$ niet van toepassing is, kan DNB van een verzekeraar verlangen dat deze een intern orgaan heeft dat een met die van een raad van commissarissen vergelijkbare taak heeft, indien dat orgaan naar het oordeel van DNB nodig is ter waarborging van de ingevolge art. 17 van het Besluit prudentiële regels Wft (Bpr) vereiste evenwichtige organisatiestructuur. DNB biedt deze ruimte overigens ook niet voor zorgverzekeraars met de nv-vorm, zie art. 3:19 lid 1 en $3 \mathrm{Wft}$. DNB is van mening dat het noodzakelijk is dat een financiële onderneming een intern toezichthoudend orgaan heeft. Ontheffingen Raad van Commissarissen $(\operatorname{RvC})$ : standpunt DNB, www.toezicht.dnb.nl/3/50-226004.jsp. Art. 3:19 Wft wordt door het wetsvoorstel gewijzigd en gaat verwijzen naar art. 2:11 BW (nieuw), zie Kamerstukken II 2015/16 34491, 2, art. VIII. 
bestuurders $^{50}$ en bij verenigingen en stichtingen ook voor commissarissen. ${ }^{51}$ Iedere bestuurder en iedere commissaris zijn tegenover de rechtspersoon gehouden tot een behoorlijke vervulling van hun taak. De bestuurders en commissarissen richten zich bij de vervulling van hun taak naar het belang van de rechtspersoon en de daaraan verbonden onderneming of organisatie. ${ }^{52}$

Hiermee wordt voor alle rechtspersonen tot uitdrukking gebracht dat de bestuurders (en commissarissen) bij de vervulling van hun taak de belangen van de rechtspersoon moeten laten prevaleren boven hun eigen belangen. ${ }^{53}$ In de formulering is (alleen) de term 'organisatie' toegevoegd omdat niet alle verenigingen en stichtingen een onderneming drijven. Met de aanduiding 'de daaraan verbonden onderneming of organisatie' wordt tot uitdrukking gebracht dat ook wanneer een rechtspersoon geen onderneming drijft, toch sprake kan zijn van een in dit kader relevant samenstel van belangen, aldus de memorie van toelichting. ${ }^{54}$

\subsection{Zorginstellingen}

Niet in het Uitvoeringsbesluit WTZi, maar in de Governancecode Zorg wordt deze norm uit Boek 2 BW ingekleurd. Bij de vervulling van zijn taak richt de raad van bestuur zich op het belang van de zorgorganisatie op korte en lange termijn, vanuit het perspectief van het realiseren van de maatschappelijke doelstelling van de zorgorganisatie en de centrale positie van de cliënt daarin. Daarbij maakt de raad van bestuur een zorgvuldige en evenwichtige afweging tussen de belangen van de cliënten, de publieke en maatschappelijke belangen, de belangen van medewerkers en de overige in aanmerking komende belangen van interne en externe belanghebbenden, zo staat in de Governancecode Zorg. ${ }^{55}$ De raad van toezicht richt zich bij de vervulling van zijn functies ${ }^{56}$ op het belang van de zorgorganisatie, vanuit het perspectief van het realiseren van de maatschappelijke doelstelling van de zorgorganisatie en de centrale positie van de cliënt daarin. De raad van toezicht toetst of de raad van bestuur alle in aanmerking komende belangen van de bij de zorgorganisatie betrokken belanghebbenden zorgvuldig en evenwichtig heeft afgewogen, aldus dezelfde code. ${ }^{57}$

Uit de bepalingen van deze Governancecode Zorg blijkt dat het belang van de zorginstelling vooropstaat, waarbij het eigen belang van de zorginstelling hoofdzakelijk wordt gekleurd door de maatschappelijke doelstelling en het geheel van de belangen van cliënten. De zorginstelling hoeft haar eigen belang daaraan niet ondergeschikt te maken. ${ }^{58}$ De Governancecode Zorg probeert verder de mogelijk

50 Zie art. 2:129/239 lid 5 BW.

51 Zie art. 2:57/140/250 lid 2 BW.

52 Art. 2:9 lid 3 en 2:11 lid 4 BW (nieuw).

53 Kamerstukken II 2015/16, 34491, 3, p. 11 en 22.

54 Kamerstukken II 2015/16, 34491, 3, p. 5 en 11.

55 Bepaling 5.3 Governancecode Zorg.

56 Toezichts-, goedkeurings-, advies- en werkgeversfunctie.

57 Bepaling 6.4.1 Governancecode Zorg.

58 Met Plomp 2016, p. 126 ben ik van mening dat de normen die de Governancecode Zorg stelt voor de taakvervulling - door de verwijzingen naar de maatschappelijke doelstelling en de centrale positie van de cliënt binnen de zorgorganisatie - derhalve iets enger zijn geformuleerd dan de norm voor de taakvervulling van bestuurders en commissarissen in Boek 2 BW. 
relevante belangen nader te duiden. Hoewel uit de volgorde wellicht zou kunnen worden afgeleid dat bepaalde belangen zwaarder wegen dan andere belangen, zal dat per situatie door het bestuur en de raad van toezicht beoordeeld moeten worden. Duidelijk is in elk geval dat het publieke belang niet prevaleert. ${ }^{59}$

\subsection{Patiëntenverenigingen}

Uit de paragraaf 'Principes van goed bestuur' van de Toolkit Goed Bestuur volgt dat het bestuur en zijn individuele leden het belang van de organisatie altijd dienen te plaatsen boven het eigen belang. Dit volgt ook uit de memorie van toelichting bij de WBTR. Een goed bestuur is volgens de Toolkit dienstbaar aan de belangen van de doelgroep van de organisatie. Vaak zal dit voortvloeien uit de doelomschrijving in de statuten. ${ }^{60}$ Het belang van de rechtspersoon kan in overwegende mate worden bepaald door de statutaire doelstelling. ${ }^{61}$

\subsection{Zorgverzekeraars}

De Wft kleurt de norm van Boek 2 BW nader in met de, op grond van art. 3:8 lid 2 Wft vereiste, zogenoemde bankierseed. Volgens bijlage 1 bij deze ministeriële regeling is onderdeel van deze eed of belofte dat de bestuurder (van een zorgverzekeraar) zweert/belooft dat hij een zorgvuldige afweging zal maken tussen alle belangen die bij de onderneming betrokken zijn, te weten die van de klanten, de aandeelhouders/leden, de werknemers en de samenleving waarin de onderneming opereert. Ook zweert/belooft hij dat hij in die afweging het belang van de klant centraal zal stellen en de klant zo goed mogelijk zal inlichten. ${ }^{62}$ In de toelichting bij deze bijlage staat dat het centraal stellen van de klant bij afweging van alle bij de onderneming betrokken belangen is opgenomen om het bijzonder kwetsbare belang van de klant te nadrukken en het betekent niet dat het belang van de klant ook automatisch voorrang heeft boven andere bij de onderneming betrokken belangen. ${ }^{63}$ Volgens de Gedragscode Goed Zorgverzekeraarschap laat de zorgverzekeraar zich in zijn ondernemingsbeleid leiden door de belangen van de verzekerde, door de maatschappelijke opvattingen ten aanzien van een verantwoorde gezondheidszorg, door wettelijke voorschriften, door het belang van een goed

59 Zie Jaarverslag 2015 van de Raad van State, jaarverslag.raadvanstate.nl/visueel/uploads/ 2016/03/RVS-Jaarverslag-2015.pdf.

60 Zie bijv. art. 3 lid 1 van de statuten van de Nederlandse Vereniging voor Autisme, dat luidt: 'De vereniging heeft ten doel de behartiging - in de ruimste zin van het woord - van de belangen van mensen met een van de aandoeningen uit het spectrum van autistische stoornissen, alsmede van aan deze personen gerelateerde belangen voor direct betrokken ouders, echtgenoten, partners, overige familieleden, voogden, curatoren, mentoren en verzorgers.'

61 Kamerstukken II 2015/16, 34491, 3, p. 12.

62 Regeling van de Minister van Financiën van 12 december 2014, kenmerk: FM 2014/1237 M, directie Financiële Markten, houdende regels met betrekking tot de door personen als bedoeld in de art. 3:8, eerste lid, 3:17b, eerste en tweede lid, 4:9, eerste lid, en 4:15a, eerste lid, van de Wet op het financieel toezicht af te leggen eed of belofte (Regeling eed of belofte financiële sector 2015), Stcrt. 2014, 37261. 
functionerend stelsel van verzekeringen en door het streven naar continuïteit van zijn onderneming. ${ }^{64}$ Dit is in mijn ogen een inkleuring van de norm in Boek 2 BW.

\section{$7 \quad$ Tegenstrijdig belang}

Met de WBTR wordt ook de tegenstrijdig-belangregeling voor alle rechtspersonen geüniformeerd. Daarmee komt voor alle rechtspersonen te gelden dat bestuurders met een tegenstrijdig belang niet mogen deelnemen aan de beraadslaging en besluitvorming over het betreffende onderwerp. Als alle bestuurders een tegenstrijdig belang hebben, kan het bestuur geen besluit nemen; in dat geval verschuift de beslissingsbevoegdheid naar de raad van commissarissen. Als er geen raad van commissarissen is, komt de bevoegdheid bij de algemene vergadering te liggen, tenzij de statuten anders bepalen. Voor de commissarissen gelden overeenkomstige regels: commissarissen met een tegenstrijdig belang mogen niet deelnemen aan de beraadslaging en de besluitvorming. Wanneer alle commissarissen een tegenstrijdig belang hebben, komt de beslissingsbevoegdheid te liggen bij de algemene vergadering. In de statuten kan overigens anders worden bepaald. ${ }^{65}$ Een stichting heeft geen algemene vergadering. Wanneer de raad van commissarissen door het tegenstrijdig belang geen besluit kan nemen of bij het ontbreken van een raad van commissarissen, wordt het besluit genomen onder schriftelijke vastlegging van de overwegingen die aan het besluit ten grondslag liggen, tenzij de statuten anders bepalen.

Met deze regeling, zo staat in de memorie van toelichting, wordt zekergesteld dat de rechtspersoon, ook in geval van tegenstrijdig belang van één of meer bestuurders of commissarissen, een besluit kan nemen. ${ }^{66}$ Mede omdat er tegenwoordig ook veel professionele organisaties zijn die de rechtsvorm van een stichting hebben, bestaat aan een dergelijke regeling behoefte. ${ }^{67}$

\subsection{Zorginstellingen}

Voor zorginstellingen met een (verplichte) raad van toezicht is deze wettelijke regeling een verbetering. Niet langer hoeft dit onderwerp in de statuten te worden geregeld. ${ }^{68}$ Het is niet wenselijk dat de eis van schriftelijke vastlegging in de statuten bij een stichting kan worden 'weggeschreven'. ${ }^{69}$ Het gaat om het afleggen van verantwoording. Voor zorginstellingen ligt transparantie over de achterliggende overwegingen altijd voor de hand. Een aanpassing van het Uitvoeringsbe-

Gedragscode Goed Zorgverzekeraarschap, 2.0.1. Zie ook Gedragscode Verzekeraars 2015, nr. 23: 'Wij stellen het klantbelang voorop, ook als spanning ontstaat tussen politieke keuzes en klantwensen.'

65 De statuten kunnen bijv. inhouden dat het besluit alsnog genomen kan worden door het bestuur of door de raad van commissarissen.

66 Kamerstukken II 2015/16, 34491, 3, p. 6.

67 Kamerstukken II 2015/16, 34491, 3, p. 5.

68 Zie bepaling 2.6.1 Governancecode Zorg; zie hierover Plomp 2016, p. 127.

69 Volgens de Gecombineerde Commissie Vennootschapsrecht sluit de wettekst (nr. 2) niet uit dat de eis van schriftelijke vastlegging kan worden 'weggeschreven'. Zie www.knb.nl/adviezen-gcv. 
sluit WTZi is op dit punt gewenst. Deze regel uit het wetsvoorstel kan, als deze in Boek 2 BW komt te staan, van dwingend recht worden verklaard.

\subsection{Patiëntenverenigingen}

Voor patiëntenverenigingen zonder een raad van commissarissen en met een algemene ledenvergadering die vaak hooguit één keer per jaar bijeenkomt, kan het de vraag zijn of de wettelijke tegenstrijdig-belangregeling (voldoende) passend is. Indien dit niet het geval is, kan de keuzevrijheid die Boek 2 BW biedt, worden benut. In de statuten kan worden opgenomen dat besluiten van een bestuur ook in het geval dat alle bestuurders een tegenstrijdig belang hebben geldig zijn. ${ }^{70}$ Hieraan kan eventueel nog de voorwaarde worden verbonden dat de algemene ledenvergadering het besluit moet goedkeuren, dat het besluit met unanimiteit moet worden genomen of dat het besluit binnen de doelomschrijving van de patiëntenvereniging moet passen. ${ }^{71}$ Dat is vaak de behartiging van de belangen van de patiënten met betrekking tot hun ziekte of aandoening. ${ }^{72}$ Wanneer de statuten van patiëntenverenigingen hierover al een bepaling kennen in verband met de vertegenwoordigingsregel, ${ }^{73}$ zullen de statuten op termijn moeten worden aangepast. $^{74}$

\subsection{Zorgverzekeraars}

Voor zorgverzekeraars is het enige verschil dat de tegenstrijdig-belangregeling een besluitvormingsregel wordt in plaats van een vertegenwoordigingsregel. ${ }^{75} \mathrm{In}$ verband met rechtszekerheid is het goed dat de OWM geen afwijkende tegenstrijdig-belangregeling kent in vergelijking tot het nv- en bv-recht en dat deze regeling voor alle rechtspersonen wordt gelijkgetrokken.

70 Heeft een bestuurder een (persoonlijk) tegenstrijdig belang als de vereniging overeenkomsten met derden aangaat, zodat leden producten met korting kunnen aanschaffen die in het belang zijn van de 'aandoening' van de leden? Bestuurders hebben vaak dezelfde aandoening als de leden, al hoeft dat niet. Zie art. 9 lid 4 van de statuten van de Parkinson Vereniging, 'de voorzitter, bij voorkeur een parkinsonpatiënt', www.parkinson-vereniging.nl/de-vereniging-pv/structuur -vereniging/anbi-publicatieverplichting/.

71 Zie Waaijer 2016, p. 67 en H.J. de Kluiver, Bezinnen en verkennen; ondernemingsrecht in de private en semipublieke sector, Kroniek van het Ondernemingsrecht, NJB 2014/796.

72 Zie bijv. art. 2 van de statuten van de Belangenvereniging Longfibrosepatiënten Nederland, www. longfibrose.nl/Bestuur\%20en\%20vereniging/Verantwoording/. Art. 2 luidt: 'De vereniging heeft ten doel: het behartigen van de belangen van longfibrosepatiënten in de ruimste zin des woords, meer speciaal op medisch, sociaal, maatschappelijk en cultureel gebied en al hetgeen daartoe behoort of bevorderlijk kan zijn.'

73 Zie bijv. art. 16 lid 4 en 5 van de Oogvereniging. Deze luiden: '4. In het geval dat zich een tegenstrijdig belang voordoet ten aanzien van een bestuurder, dient de desbetreffende bestuurder dit onverwijld te melden aan de overige bestuurders. De desbetreffende bestuurder dient zich voorts van de beraadslaging en besluitvorming ter zake te onthouden. De aanwezigheid van de desbetreffende bestuurder telt niet mee ter bepaling of het vereiste quorum voor de besluitvorming is behaald. 5. In geval van een tegenstrijdig belang tussen één of meer bestuurders en de Vereniging, wordt de Vereniging vertegenwoordigd door het voltallig bestuur, dan wel door de persoon of personen die daartoe door de ledenraad zijn aangewezen.'

74 Zie Waaijer 2016, p. 67.

75 Art. 2:57 lid 4 BW vervalt. De WBTR (nr. 2) bevat geen overgangsrecht, zie hierover Gecombineerde Commissie Vennootschapsrecht, www.knb.nl/adviezen-gcv. 


\section{Aansprakelijkheid van bestuurders en commissarissen}

Naar huidig en komend recht kunnen bestuurders van alle rechtspersonen bij onbehoorlijke taakvervulling aansprakelijk worden gesteld. ${ }^{76}$ Met de WBTR kunnen commissarissen van alle rechtspersonen (en niet alleen van commerciële verenigingen en stichtingen) ook aansprakelijk worden gesteld voor onbehoorlijke taakvervulling. ${ }^{77}$ Dit wordt dus verruimd tot alle verenigingen en stichtingen. ${ }^{78}$ Met de WBTR kunnen zowel bestuurders als commissarissen van alle rechtspersonen in geval van faillissement jegens de boedel hoofdelijk aansprakelijkheid worden gesteld voor het tekort. ${ }^{79}$ Naar huidig recht geldt dit niet voor niet-commerciële verenigingen en niet-commerciële stichtingen. ${ }^{80}$

Deze laatste aanscherping is, volgens de memorie van toelichting, van belang omdat het ook bij die rechtspersonen kan voorkomen dat bestuurders en commissarissen zich schuldig maken aan fraude of andere vormen van ernstig taakverzuim. De curator dient dan adequate middelen te hebben om de geleden schade te verhalen op de bestuurders en commissarissen die hun taken ernstig hebben verzuimd. Een van die middelen is het bewijsvermoeden van art. 2:9c lid 2 BW (nieuw):

'Indien het bestuur niet heeft voldaan aan zijn verplichtingen uit art. 2:10 BW of art. 2:394 BW heeft het zijn taak kennelijk onbehoorlijk vervuld en wordt vermoed dat onbehoorlijke taakvervulling een belangrijke oorzaak is van het faillissement.'

In de consultatie was op deze aanscherping veel kritiek. ${ }^{81}$ In het wetsvoorstel is hieraan tegemoetgekomen door te bepalen dat het lid over het bewijsvermoeden niet geldt voor een onbezoldigd bestuurder van een vereniging of stichting die niet aan de heffing van de vennootschapsbelasting is onderworpen en dat het lid niet geldt voor een onbezoldigd bestuurder van een informele vereniging. Van een onbezoldigde functie als bedoeld in deze bepaling zal sprake zijn als de bestuurder voor zijn werkzaamheden geen vergoeding ontvangt of enkel een vergoeding voor werkelijk gemaakte onkosten. Deze aanvulling strekt ertoe om te voorkomen dat vrijwilligers ten onrechte ervan worden weerhouden om zich in te

Art. 2:9 BW en art. 2:9b BW (nieuw).

Zie voor de 'van overeenkomstige toepassing'-verklaring art. 2:9 BW. de nv (art. 2:149 BW), de bv (art. 2:259 BW), de commerciële vereniging (art. 2:50a BW), de coöperatie en OWM (art. 2:50a en 2:53a lid 1 BW) en de commerciële stichting (art. 2:300a BW).

Art. 2:11b BW.

Art. 2:9c en 2:11c BW (nieuw).

Art. 2:138 (jo. art. 2:149) BW geldt op grond van schakelbepalingen ook voor de commerciële vereniging, de coöperatie, de OWM en de commerciële stichting (art. 2:50a, 2:53a en 2:300a BW).

In de consultatie is erop gewezen dat de toepassing van de bedoelde regeling op alle rechtspersonen het voor kleine, niet-commerciële verenigingen en stichtingen moeilijker kan maken om vrijwilligers te vinden voor de vervulling van bestuurs- of commissarisfuncties. Ook de Commissie vennootschapsrecht heeft op dit risico gewezen. 
zetten als bestuurder of commissaris van bijvoorbeeld een buurtvereniging of een kleine sportvereniging, aldus de memorie van toelichting. ${ }^{82}$

\subsection{Zorginstellingen}

Door het wetsvoorstel wordt de aansprakelijkheid van bestuurders en leden van de raad van toezicht van zorginstellingen aangescherpt.

Voor leden van de raad van toezicht gaat op grond van Boek 2 BW gelden dat zij aansprakelijk zijn indien zij hun taak onbehoorlijk vervullen. ${ }^{83}$ Gezien de professionalisering die de (leden van de) raad van toezicht in de zorg doormaakt en moet doormaken, wordt een lacune in de aansprakelijkheidsregeling opgevuld. ${ }^{84}$ Indien dit wetsvoorstel dit niet had gedaan, was er specifieke zorgwetgeving gekomen. ${ }^{85}$ Voor zowel bestuurders als leden van de raad van toezicht van zorginstellingen betekent het wetsvoorstel dat zij aansprakelijk zijn voor onbehoorlijk bestuur in geval van faillissement. Dit past ook binnen de zienswijze dat van bestuurders en leden van de raad van toezicht van zorginstellingen het een en ander verwacht wordt. De aansprakelijkheid wordt hiermee duidelijk aangescherpt, mede doordat faillissementen in de zorg een realiteit zijn. ${ }^{86}$ De uitzondering van het bewijsvermoeden geldt niet voor bestuurders en leden van de raad van toezicht van zorginstellingen, omdat zij een betaalde functie hebben. Zij worden betaald volgens de normen van de Wet normering bezoldiging topfunctionarissen publieke en semipublieke sector (WNT). Het bewijsvermoeden werkt ook nog eens ten nadele van zorginstellingen, omdat door niet-eenduidige wet- en regelgeving over de wijze van declareren moeilijk voldaan kan worden aan de verplichting om de jaarrekening tijdig te deponeren. Dit geldt bijvoorbeeld voor de ggz-sector. ${ }^{87}$ Plomp pleit er zelfs voor om het bewijsvermoeden voor zorginstellingen buiten toepassing te verklaren zolang de problemen met betrekking tot de declaratieregelgeving niet zijn opgelost. ${ }^{88}$ Zo ver zou ik (nog) niet willen gaan, maar dat dit onderwerp hoog op het prioriteitenlijstje van de minister van VWS moet staan, lijkt mij duidelijk. Hoewel aangetoond zou kunnen worden dat er een andere belangrijke oorzaak is voor het faillissement, moet hierdoor de bewijslast niet 'automatisch' naar de bestuurders en leden van de raad van toezicht van zorginstellingen verschuiven. Huidige en toekomstige bestuurders en leden van de raad van toezicht van zorginstellingen die zichzelf geschikt achten voor hun taak zullen zich door deze nieuwe regels niet laten afschrikken, zo is mijn verwachting. Ook de minister lijkt

82 Kamerstukken II 2015/16, 34491, 3, p. 7.

83 Rb. Amsterdam 26 maart 2008, JOR 2008/126 (Hestia) heeft bevestigd dat art. 2:9 BW niet van toepassing is op de taakvervulling door de raad van toezicht bij een stichting.

84 A.G.H. Klaassen, Goed bestuur in de Wet cliëntenrechten zorg, TvGR 2011, p. 386; Houwen 2014, p. 146.

85 Art. 40 lid 5 van het wetsvoorstel Wet cliëntenrechten zorg verklaarde art. 2:9 BW van overeenkomstige toepassing op leden van het toezichthoudend orgaan.

86 De Stichting Ruwaard van Putten Ziekenhuis is 24 juni 2013 door de Rechtbank Den Haag failliet verklaard. Kamerstukken II 2012/13, 31016, 44, p. 1. In november 2014 is de eigenaar van het ziekenhuis De Sionsberg, de Zorggroep Pasana, failliet verklaard. Ook een aantal thuiszorginstellingen is failliet gegaan, bijv. Het Zorgbureau Twente.

87 Zie bijv. Skipr Daily 26 februari 2016 (NZa verruimt regels jaarrekeningen ggz).

88 Plomp 2016, p. 146. 
het risico dat het moeilijker wordt om leden voor de raad van toezicht te vinden laag in te schatten. ${ }^{89}$

\subsection{Patiëntenverenigingen}

Ook voor bestuurders (en voor eventuele commissarissen) van patiëntenverenigingen gaat de mogelijkheid van aansprakelijkheid voor het tekort bij onbehoorlijk bestuur in geval van faillissement gelden. Ervan uitgaande dat (de meeste) bestuurders van patiëntenvereniging hun functie onbezoldigd vervullen, ${ }^{90}$ is het bewijsvermoeden niet op hen van toepassing.

De vraag is of deze aanscherping wenselijk is. Voor een verzwaring van deze aansprakelijkheid van bestuurders bestaat in mijn ogen geen enkele noodzaak. ${ }^{91}$ Deze noodzaak is er pas als aangetoond kan worden dat bestuurders zich schuldig maken aan fraude of andere vormen van ernstig taakverzuim (en de vereniging hierdoor failliet gaat) en dat het gaat om meer dan een incident. ${ }^{92}$ De kans dat een curator een beroep zal doen op deze wetsbepaling acht ik niet groot, omdat een patiëntenvereniging (hopelijk) niet gauw failliet zal gaan, ${ }^{93}$ maar het is de vraag of verzekeraars van beroepsaansprakelijkheidsverzekeringen daarover ook zo denken. ${ }^{94}$ In elk geval dienen de premies voor patiëntenverenigingen betaalbaar te blijven gezien de beperkt beschikbare subsidies. ${ }^{95}$ Het lijkt mij dat voor (huidige en toekomstige) bestuurders van patiëntenverenigingen de aanscherping

89 Kamerstukken II 2014/15, 32012, 24, p. 47. Zij verwijst naar A. Gelderblom, J. de Koning, T. Viertelhausen, K. Weistra \& S. van de Veerdonk, De arbeidsmarkt van interne toezichthouders onder de loep, Rotterdam: SEOR/Ecorys 2014; zie www.rijksoverheid.nl/ministeries/ez/ documenten-en-publicaties/rapporten/2014/11/13/eindrapport-de-arbeidsmarkt-van-internetoezichthouders-onder-de-loep.html. Hierin staat op p. iv en 63: '(...) de aansprakelijkheid [speelt] slechts een beperkte rol als knelpunt om een toezichtfunctie te (willen of blijven) vervullen.'

90 Zie art. 14 lid 4 van de statuten van de Oogvereniging, www.oogvereniging.nl/wp-content/ uploads/2015/06/Statuten.pdf. Lid 4 luidt: 'Bestuurders kunnen - ter beoordeling van de ledenraad - recht hebben op vergoeding van de door hen in uitoefening van hun functie (in redelijkheid) gemaakte kosten en kunnen voorts een niet bovenmatig vacatiegeld ontvangen ter zake van hun werkzaamheden voor de Vereniging.'

91 Voor alle niet-commerciële rechtspersonen, zie C.H.C. Overes, Aansprakelijkheid van stichtingsbestuurders; bestuurders opgelet!, Ondernemingsrecht 2015/103, p. 525.

92 Zie ook J.M. Blanco Fernández, Toezicht in het rechtspersonenrecht in het wetsvoorstel Bestuur en toezicht, in: J.M. Blanco Fernández e.a., Bestuur en toezicht bij rechtspersonen, mede in de semipublieke en non-profitsector, Zutphen: Uitgeverij Paris 2016, p. 46. Voor dat ene incident kan er een beroep worden gedaan op art. 2:9 of 6:162 BW door de zorginstelling of derden. Zie Hof Amsterdam 12 juni 2012, RO 2012/62 (Nederlandse Rode Kruis), de penningmeester was aansprakelijk op grond van art. 2:9 BW voor fraude door de secretaris.

93 Bestuurders wordt geleerd niet meer uit te geven dan er binnenkomt ('dan maar een activiteit minder').

94 Zie ook B.A. de Ruijter, Storm op komst voor bestuurders en commissarissen in de semipublieke sector, MvO 2016, p. 191.

95 Verhoging van de contributie is vaak geen alternatief. Leden zeggen vaak hun lidmaatschap op na een contributieverhoging, terwijl patiëntenverenigingen juist opgericht zijn ten behoeve van patiënten met een bepaalde aandoening. 
van aansprakelijkheid, indien zij zich daarvan bewust zijn, ${ }^{96}$ zeker een rol zal kunnen spelen bij het (gaan) uitoefenen van deze functie. ${ }^{97}$ Het gaat om een onbetaalde vrijwilligersfunctie die in de vrije tijd wordt vervuld. Daaraan kunnen niet dezelfde eisen worden gesteld als aan professionele bestuurders van zorginstellingen en zorgverzekeraars. ${ }^{98}$ In mijn ogen zou dit artikel in elk geval niet van toepassing moeten zijn op patiëntenverenigingen.

\subsection{Zorgverzekeraars}

Voor bestuurders en commissarissen van zorgverzekeraars wijzigt er op dit punt niets.

\section{Ontslag door rechter}

De WBTR bevat een aangepaste regeling voor ontslag van een stichtingsbestuurder door de rechter. De ontslaggronden van art. 2:298 BW worden door het wetsvoorstel verruimd. Een stichtingsbestuurder kan door de rechter worden ontslagen wegens (1) verwaarlozing van zijn taak, (2) andere gewichtige redenen, (3) ingrijpende wijziging van omstandigheden op grond waarvan het voortduren van het bestuurderschap in redelijkheid niet geduld kan worden, en (4) het niet of niet-behoorlijk voldoen aan een bevel van de voorzieningenrechter. ${ }^{99}$

In de praktijk, zo staat in de memorie van toelichting, blijken de huidige ontslaggronden in bepaalde gevallen niet toereikend om het ontslag te bewerkstelligen van een bestuurder die het belang van de stichting zodanig schaadt dat het niet langer verantwoord is om hem als bestuurder te handhaven. ${ }^{100}$ Dit kan er onder omstandigheden toe leiden dat de continuïteit van de betreffende stichting in gevaar komt. In geval van stichtingen die actief zijn in semipublieke sectoren kan daardoor mogelijk ook de uitvoering van diensten of taken van publiek belang in het gedrang komen. ${ }^{101}$ Volgens de memorie van toelichting past de voorgestelde regeling hiermee beter bij de functie die stichtingen vandaag de dag in het maatschappelijke en economische verkeer vervullen. ${ }^{102}$ In sectorspecifieke wetgeving kan deze basisregeling zo nodig worden aangevuld. ${ }^{103}$

Wanneer er bij de stichting een raad van commissarissen is ingesteld, is dat orgaan vanwege het ontbreken van een algemene vergadering niet onderworpen

96 Dat zouden de toekomstige bestuurders moeten zijn, maar in de praktijk staat dit onderwerp bij de aanvaarding van een functie niet als eerste op het netvlies.

97 Zie ook Blanco Fernández 2016, p. 46 en De Ruijter 2016, p. 191.

98 Zie ook het advies van de Raad van State, Kamerstukken II 2015/16, 34491, 4, p. 10.

99 Met de regeling wordt, mede naar aanleiding van het advies van de Commissie vennootschapsrecht, aangesloten bij de criteria voor ontslag van een commissaris van een structuurvennootschap door de Ondernemingskamer (zie art. 2:161 lid 2 en 2:271 lid 2 BW).

100 Ontslag door de rechter kan daardoor pas plaatsvinden als redelijkerwijs geen twijfel kan bestaan over de onrechtmatigheid van het handelen of wanneer sprake is van financieel wanbeheer, zie HR 3 januari 1975, NJ 1975/222.

101 Kamerstukken II 2015/16, 34491, 3, p. 8.

102 Kamerstukken II 2015/16, 34491, 3, p. 8.

103 Kamerstukken II 2015/16, 34491, 3, p. 35. 
aan een vorm van interne controle. De ontslagmogelijkheid door een rechter kan dan wenselijk zijn. De regeling van ontslag van een stichtingsbestuurder wordt met het wetsvoorstel van overeenkomstige toepassing verklaard op de commissaris van een stichting. ${ }^{104}$

\subsection{Zorginstellingen}

Leden van de raad van toezicht kunnen momenteel niet worden ontslagen op grond van art. 2:298 BW. Op grond van art. 2:298 lid 4 BW (nieuw) kan dit wel. Deze aanscherping past bij de professionaliseringsslag van de leden van de raad van toezicht van zorginstellingen.

Voor bestuurders en leden van de raad van toezicht houdt het wetsvoorstel ook in dat de drempel voor ontslag door de rechter lager wordt, omdat de gronden van art. 2:298 BW worden verruimd. Met deze gronden ${ }^{105}$ wordt, mede naar aanleiding van het advies van de Commissie vennootschapsrecht, aangesloten bij de criteria voor ontslag van een commissaris van een structuurvennootschap door de Ondernemingskamer. ${ }^{106}$ In de literatuur worden voor 'andere gewichtige redenen' situaties genoemd waarin de commissaris (of bestuurder in geval van art. 2:298 BW) betrokken is geraakt in een schandaal of actief is geworden bij een direct concurrerende vennootschap. Onder 'ingrijpende wijziging van omstandigheden' valt te denken aan een situatie dat een commissaris moet opstappen in het geval van een juridische fusie. ${ }^{107}$ Deze voorbeelden leiden er niet meteen toe om te veronderstellen dat deze gronden zullen leiden tot onwenselijke gevolgen. Dit soort situaties worden door de Governancecode Zorg ook als ongewenst gezien. ${ }^{108}$ Bovendien moet art. 2:298 BW worden gezien als een escape wanneer bestuurders en leden van de raad van toezicht zelf niet ingrijpen bij ongewenst gedrag van een collega-lid. Zij moeten het zover niet laten komen. ${ }^{109}$ Het enige punt van zorg van mijn kant is hoe deze verruiming van gronden zich verhoudt tot het bestuursverbod in lid 3 van art. 2:298 BW. Betekent een ontslag op de genoemde gronden meteen dat een bestuurder of commissaris ongeschikt is ${ }^{110}$

Met Plomp ben ik van mening dat de WBTR aanleiding geeft tot heroverweging van de aan de Inspectie voor de Gezondheidszorg (IGZ) gemandateerde bevoegdheid om aanwijzingen te geven die ingrijpen in (de samenstelling van) het bestuur en de raad van toezicht van zorginstellingen. ${ }^{111}$ Op grond van art. 27 van de Wet kwaliteit, klachten en geschillen zorg (Wkkgz) kan IGZ aanwijzingen geven als de kwaliteit van zorg bij een zorginstelling niet in orde is. Bij het (structureel) herstel van goede zorgverlening kan een aanwijzing zelfs bestaan uit het vervangen van

104 Art. 2:298 lid 4 BW (nieuw). Kamerstukken II 2015/16, 34491, 3, p. 8.

105 Blanco Fernández 2016, p. 55 stelt voor de tekst te wijzigen in 'wegens ernstige verwaarlozing van zijn taak'.

106 Art. 2:161 lid 2 en 2:271 lid 2 BW. Zie Kamerstukken II 2015/16, 34491, 3, p. 8.

107 Slagter/Assink, Compendium van het Ondernemingsrecht, Deventer: Kluwer 2013, p. 1257.

108 Zie bijv. bepaling 2.1.2, 2.6.1 en 6.5.5 Governancecode Zorg.

109 Vgl. bepaling 2.2.1 Governancecode Zorg.

110 A.G.H. Klaassen, Bestuurderstoets voor de zorg (of niet)?, TvGR 2014, p. 646.

111 Plomp 2016, p. 142. 
één of meer leden van het bestuur of de raad van toezicht. ${ }^{112}$ Een dergelijke inmenging in de privaatrechtelijke verhoudingen gaat wel erg ver als het gaat om het functioneren van individuele bestuurders en leden van de raad van toezicht. Er zou door VWS (en IGZ) nog eens goed moeten worden gekeken naar de toepassing van art. 27 Wkkgz wat betreft dit aspect en de samenloop met art. 2:298 BW. ${ }^{113}$ Deze laatste weg biedt de bestuurder en leden van de raad van toezicht ook meer rechtsbescherming.

\subsection{Patiëntenverenigingen en zorgverzekeraars}

Art. 2:298 BW is niet van toepassing op verenigingen en OWM's.

\section{Conclusie}

Wat betekent de WBTR voor zorginstellingen, patiëntenverenigingen en zorgverzekeraars? De WBTR heeft met de voorgestelde tekst vooral gevolgen voor zorgstichtingen en in mindere mate voor patiëntenverenigingen. Voor zorgverzekeraars verandert er nog minder. Op sommige punten zal sectorale regelgeving nodig zijn om Boek 2 BW aan te vullen. Bovendien dienen zorginstellingen na te gaan of hun statuten in overeenstemming zijn met de wijzigingen door de WBTR. Patiëntenverenigingen dienen eventueel hun statuten aan te passen aan de ruimte die de WBTR biedt. Dit geldt voor de situatie dat alle bestuurders een tegenstrijdig belang hebben.

Zijn de gevolgen (van de WBTR) wenselijk? Voor de zorginstellingen passen de voorgestelde wijzigingen bij de professionalisering die het bestuur en toezicht in deze instellingen doormaken. Voor patiëntenverenigingen zijn de gevolgen op het gebied van aansprakelijkheid van bestuurders te ingrijpend. De beperkte gevolgen voor de zorgverzekeraars zijn passend.

Is aanpassing van sectorale regelgeving nodig of gewenst? Aanpassing van het Uitvoeringsbesluit WTZi (of de WTZi) is op een aantal punten gewenst. De regels dienen zodanig te worden aangepast dat een monistisch bestuursmodel mogelijk is voor zorginstellingen. Van dwingend recht moet worden dat schriftelijk moet worden vastgelegd wat de overwegingen zijn bij een tegenstrijdig belang van alle leden van de raad van toezicht van een zorginstelling. Om de aanscherping van aansprakelijkheid van bestuurders en leden van de raad van toezicht zonder onbedoelde neveneffecten te laten verlopen, is het zaak dat VWS de aanpassing van de declaratieregels topprioriteit geeft, zodat zorginstellingen niet om die reden geen jaarrekening kunnen publiceren.

Aanpassing van de Zvw is op zich niet nodig. Wel is van belang dat VWS en DNB duidelijk maken dat een monistisch model een mogelijkheid is voor zorgverzekeraars.

112 Kamerstukken II 2015/16, 32012, 35, p. 8. Volgens J.G. Sijmons, Over de 'open normen' van goed bestuur en handhaving na invoering van de Wkkgz, TvGR 2016, p. 90 bestaat daarvoor geen grondslag in de Wet kwaliteit, klachten en geschillen zorg.

113 De Staat kan een belanghebbende zijn in de zin van art. 2:298 BW, zie Kamerstukken II 2015/16, 34491, 3, p. 35 en Rb. Den Bosch 30 januari 2008, JOR 2008/69. 
Aanpassing van de tekst van de WBTR is gewenst op het punt van de aansprakelijkheid van bestuurders (en commissarissen) van (patiënten)verenigingen in faillissement.

De WBTR heeft voor zorginstellingen, zorgverzekeraars en patiëntenverenigingen zeker gevolgen, voor de een meer dan voor de ander. 